\title{
ORIGINAL
}

\section{Chemical Stopper for Runaway Propoxylation}

\author{
Yoshikazu GoTOH* and Takao ANDOH** \\ * Nagoya Factory Sanyo Chemical Industries, LTD \\ (31-1, Shinpoh, Tohkai-shi, Aichi-ken, T476) \\ ** Research Dept. Research Division Sanyo Chemical Industries, LTD \\ (11-1, Ikkyo Nomoto, Higashiyama-ku, Kyoto-shi, ₹605)
}

Propoxylation becomes important more and more for making materials of urethane foam and surfactants in industry.

The actual production of polyether polyols for urethane foam amounted to $297,750 t$ in 1990 , and was estimated at $300,000 \mathrm{t}$ in 1991 .

However, propylene oxide (PO) is one of a low-boiling-point monomer which reacts so fast at high temperature, that it is very important to know how to stop propoxylation when it becomes uncontrollable. In this paper, it was proved that runaway propoxylation could be stopped with dosing phsphoric acid in reaction mass.

\section{Introduction}

In the previous report, an equation for maximum pressure and temperature in the runaway propoxylation was proposed ${ }^{1)}$.

The pressure of runaway propoxylation could be calculated by the following numerical expression.

$$
\begin{aligned}
\log P= & (\log C / 1.3238)-(1,066.4 / T) \\
& +2.5040
\end{aligned}
$$

$C: \mathrm{PO}$ concentration in reaction mass (wt \%)

$P$ : abs. pressure $\left(\mathrm{kgf} / \mathrm{cm}^{2}\right)$

$T$ : abs. temperature (K)

And its validity demonstrated by adiabatic experiments using "Reaction Calorimeter $\mathrm{RC}-1$ ".

It is proved distinctly that maximum pressure is not so high as believed before, but rise of temperature is in dangerous range.

If reaction temperature rises over $200^{\circ} \mathrm{C}$, the $\mathrm{TU}$ value (terminal unsatulation, allyl and propenyl ether compounds) increases in number and the value of products decreases. And if it rises over $300^{\circ} \mathrm{C}$, reaction apparatus becomes in danger. If it is possible to stop runaway propoxylation, temperature

Corresponding author : Yoshikazu GOTOH rises not so high, and products is re-useful with low TU value. In the past, it was popular that cooling of out walls of reaction apparatus with a large quantity of falling water when it ran away. It was known well that propoxylation could not occure with neutralization of catalizer, but was not confirmed the effect of neutralization after it ran away. And scarecely any preventive

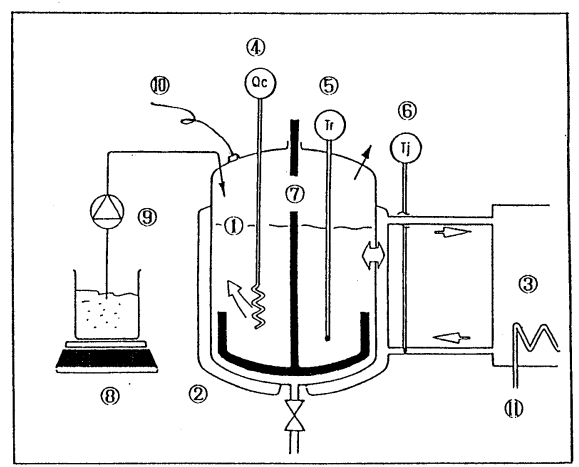

The explanation of them are as follows.

(1) Reactor (Autoclave) (2) Jacket (3) Silicone oil tank (4) Calibration heater (5) Thermometer in reaction mass (6) Thermometer in jacket (7) $\mathrm{Ag}$ itator (8) Platform scale for dosing (9) Control valve for dosing (10) Pressure sensor (11) Cooling water

Fig.-1 Apparatus of reaction calorimeter $\mathrm{RC}-1$. 
Table-1 Calculated maximum pressure and temperature in runaway propoxylation.

\begin{tabular}{c|c|c|c}
\hline Condition & $\begin{array}{c}105^{\circ} \mathrm{C} \times \\
22 \mathrm{wt} \%\end{array}$ & $\begin{array}{c}105^{\circ} \mathrm{C} \times \\
33 \mathrm{wt} \%\end{array}$ & $\begin{array}{c}120^{\circ} \mathrm{C} \times \\
33 \mathrm{wt} \%\end{array}$ \\
\hline $\begin{array}{c}\text { Abs. press. } \\
\left(\mathrm{kgf} / \mathrm{cm}^{2}\right)\end{array}$ & 7.4 & 14.0 & 16.4 \\
\hline Temperature $\left({ }^{\circ} \mathrm{C}\right)$ & 234 & 298 & 312 \\
\hline
\end{tabular}

(Condition : $105^{\circ} \mathrm{C} \times 22$ wt $\% \rightarrow$ reaction temperature is $105^{\circ} \mathrm{C}$, and $\mathrm{PO}$ concentration in reaction mass is 22 wt \% when Ad mode stars)

measures had been taken against runaway propoxylation. In this paper, it was proved that neutralization of catalizer, even if propoxylation already ran away, was effective to stop it by adiabatic experiments using "Reaction Calorimeter RC-1".

Catalizers well known in propoxylation are, inorganic bases ${ }^{2) \sim 4}$, alcoholate ${ }^{5), 6)}$, alumina ${ }^{7)}$, organic metal ${ }^{8)}$ and iron(III) chloride ${ }^{9), 10)}$. And inorganic bases are popular most for propoxylation, we selected anhydrous potassium hydroxide as catalizer, and phosphoric acid, being less corrosive to reacter, as chemical stopper for runaway propoxylation.

\section{Experimental}

We used Reaction Calorimeter $\mathrm{RC}-1^{1)}$. Device for propoxylation and dosing phosphoric acid for the foliowing experiments is shown in Fig. -2 .

The operation of it is as follows.

Preparation : Open valve-1 (valves-2,3 and 4 are closed) and dose proper quantity of phosphoric acid into hopper, and close valve-1.

Operation : When propoxylation runs away, stop PO dosing first, (continue stirring) and open valves -2 and 3 with remote control, next open valve- 4 in the same way.

$\mathrm{PO}$ concentration in reaction mass is calculated by following equation ${ }^{1)}$.

$\log C=1.3238 \log P+(1,411.7 / T)-3.3148$

Experimented 7 terms are as follows.

Exp. 1

Polyether polyol A (Glycerol/PO adduct, M.W. 2,$000 ; 500 \mathrm{~g}$ ), and $2.5 \mathrm{~g}$ (purity-accounted) of anhydrous potassium hydroxide

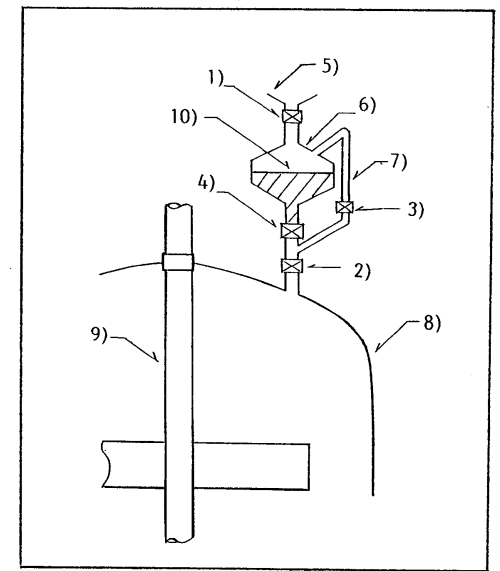

The explanation of them are as follows.

1) Valve-1 2) Valve-2 3) Valve-3 4) Valve-4

5) Hopper 6) Stock tank 7) Connected pipe

8) Reactor 9) Agitator 10) Phosphoric acid

Fig.-2 Device for dosing phosphoric acid.

( $\mathrm{KOH})$ are charged in $\mathrm{RC}-1$, and controlled at $105{ }^{\circ} \mathrm{C}$ under stirring. After this treatment, dosing of $\mathrm{PO}$ is started under $0 \mathrm{kgf} /$ $\mathrm{cm}^{2}$, then pressure and temperature are controlled at $6.0 \mathrm{kgf} / \mathrm{cm}^{2}$ and $105^{\circ} \mathrm{C}$, and now $\mathrm{PO}$ concentration of reaction mass is found to be about 28 wt \%. Then, PO dosing is stopped and reaction is changed to Ad mode (adiabatic mode, controlled without heat of reaction loss automatically by $\mathrm{RC}-1$ ).

Exp. 2

Polyether polyol A $(500 \mathrm{~g})$, and $2.5 \mathrm{~g}$ of $\mathrm{KOH}$ are charged in $\mathrm{RC}-1$, and controlled at $105^{\circ} \mathrm{C}$ under stirring. After this treatment, dosing of $\mathrm{PO}$ is started under $0 \mathrm{kgf} / \mathrm{cm}^{2}$, then pressure and temperature are controlled at $6.0 \mathrm{kgf} / \mathrm{cm}^{2}$ and $105^{\circ} \mathrm{C}$. Then, PO dosing is stopped and reaction is changed to Ad mode. After $5 \mathrm{~min}, 2.4 \mathrm{~g}(0.5 \mathrm{~mol}$ equivalent) of $90 \%$ aqueous phosphoric acid is dosed in reaction mass.

Exp. 3

Polyether polyol A (500 g), and $2.5 \mathrm{~g}$ of $\mathrm{KOH}$ are charged in $\mathrm{RC}-1$, and controlled at $120^{\circ} \mathrm{C}$ under stirring. After this treatment, dosing of $\mathrm{PO}$ is started under $0 \mathrm{kgf} /$ $\mathrm{cm}^{2}$, then pressure and temperature are controlled at $7.0 \mathrm{kgf} / \mathrm{cm}^{2}$ and $120^{\circ} \mathrm{C}$, and now $\mathrm{PO}$ concentration of reaction mass is found to be about 28 wt $\%$. Then, PO dosing 
is stopped and reaction is changed to $\mathrm{Ad}$ mode.

Exp. 4

Polyether polyol A $(500 \mathrm{~g})$, and $2.5 \mathrm{~g}$ of $\mathrm{KOH}$ are charged in $\mathrm{RC}-1$, and controlled at $120^{\circ} \mathrm{C}$ under stirring. After this treatment, dosing of $\mathrm{PO}$ is started under $0 \mathrm{kgf} /$ $\mathrm{cm}^{2}$, then pressure and temperature are controlled at $7.0 \mathrm{kgf} / \mathrm{cm}^{2}$ and $120^{\circ} \mathrm{C}$. Then, $\mathrm{PO}$ dosing is stopped and reaction is changed to Ad mode. After, 5 min $3.4 \mathrm{~g}$ (0.7 mol equivalent) of $90 \%$ aqueous phosphoric acid is dosed in reaction mass.

Exp. 5

Polyether polyol A $(500 \mathrm{~g})$, and $2.5 \mathrm{~g}$ of $\mathrm{KOH}$ are charged in $\mathrm{RC}-1$, and controlled at $105{ }^{\circ} \mathrm{C}$ under stirring. After this treatment, dosing of $\mathrm{PO}$ is started under $0 \mathrm{kgf} /$ $\mathrm{cm}^{2}$, then pressure and temperature are controlled at $6.0 \mathrm{kgf} / \mathrm{cm}^{2}$ and $105^{\circ} \mathrm{C}$. Then, $\mathrm{PO}$ dosing is stopped and reaction is changed to Ad mode. After $5 \mathrm{~min}, 1.6 \mathrm{~g}$ ( 0.33 mol equivalent) of $90 \%$ aqueous phosphoric acid is dosed in reaction mass.

Exp. 6

Polyether polyol A (500 g), $2.5 \mathrm{~g}$ of $\mathrm{KOH}$ and $2.4 \mathrm{~g}$ of $90 \%$ aqueous phosphoric acid are charged in $\mathrm{RC}-1$. After $2 \mathrm{~h}$ stirring under reduced pressure at $105^{\circ} \mathrm{C}$, reaction is started under $\mathrm{Tr}$ mode (reaction temperature mode, controlled at fixed temperature automatically by $\mathrm{RC}-1$ ) with dosing $\mathrm{PO}$ under $0 \mathrm{kgf} / \mathrm{cm}^{2}$, then pressure and temperature are controlled at $6.0 \mathrm{kgf} / \mathrm{cm}^{2}$ and 105 ${ }^{\circ} \mathrm{C}$.

Exp. 7

Polyether polyol B (produced by Exp. 2) $(500 \mathrm{~g}), 3.5 \mathrm{~g}$ of $\mathrm{KOH}$ are charged in $\mathrm{RC}-1$. After $2 \mathrm{~h}$ stirring under reduced pressure at $105^{\circ} \mathrm{C}$, reaction is started under $\operatorname{Tr}$ mode with dosing $\mathrm{PO}$ under $0 \mathrm{kgf} / \mathrm{cm}^{2}$, then pressure and temperature are controlled at 6.0 $\mathrm{kgf} / \mathrm{cm}^{2}$ and $105^{\circ} \mathrm{C}$.

\section{Results and Discussion}

The results of Exp. 1 7 are shown in Figs. $-3,4$ and -5 .

Fig. -3 and -5 (Exp. 2,4) show that reaction is nearly stopped by dosing of phosphoric acid in reaction inass. And no heat of re- action is observed in Exp. 6, neutralization of potassium hydroxide catalizer by phosphoric acid is effective for stopping of runaway propoxylation.

Proper quantity of phosphoric acid is over $0.5 \mathrm{~mol}$ equivalent to added potassium hydroxide. Exp. 5 shows that 0.33 mol equivalent is not enough to stop runaway propoxylation. In this case, phosphoric acid could be regarded as dibased acid.

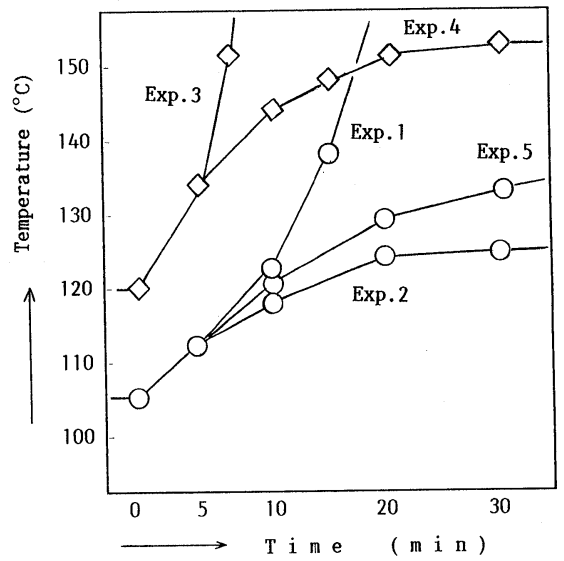

Fig.-3 Temperature of adiabatic propoxylation.

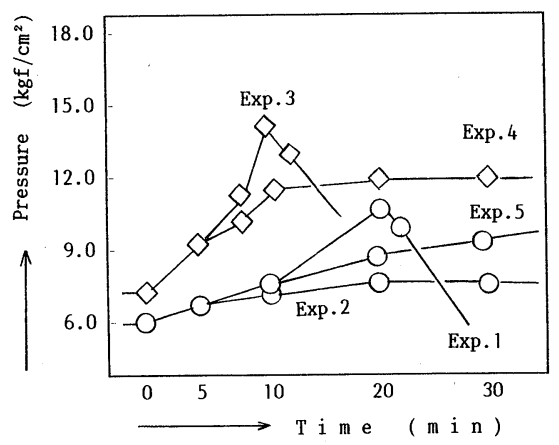

Fig. -4 Pressure of adiabatic propoxylation.

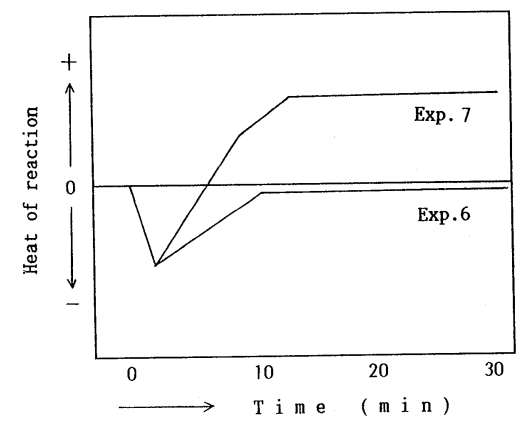

Fig. -5 Heat of reaction (Evaluated by $\mathrm{RC}-1$ ) 
(Received June 25, 1992)

\section{References}

1) Y. Gotoh, J. Jpn. Oil Chem. Soc. (YUKAGAKU) , 41, 489 (1992).

2) L.E. St. Pierre and C. C. Price, J. Am. Chem. Soc. 78, 3432 (1956).

3) Levene, J. Biol. Chem. 75, 325 (1927).

4) L.G. Lundsted, US Pat., 2,677,760 (1954).

5) E.T. Borrows and D.G. Stwart, Brit. Pat., 785,053 (1957) ; US Pat., 2,870,099 (1959).

6) D.G. Stewart and E.T. Borrows, Brit. Pat., 785,053 (1958).

7) Mönster, DR Pat., 821,349 (1951).

8) D.G. Stewart, D.Y. Waddan, and E.T. Borrows, Brit Pat., 785,229 (1957) ; US Pat., 2,870,100 (1959).

9) C.D. Price, M. Osgan, R.E. Hughes, and C. Chembelan, J. Am. Chem. Soc. 78, 690 (1956).

10) C.C. Price and M. Osgan, J. Am. Chem. Soc. 78, 4787 (1956).

\section{Key Words}

chemical stopper, ranaway propoxylation, potassium hydroxide, phosphoric acid, Reaction Calorimeter $\mathrm{RC}-1$, propoxylation, neutralization of catalizer.
暴走プロポキシレーションにおける

$$
\text { ケミカルストッパー }
$$

\section{五藤芳和 ${ }^{*} \cdot$ 安藤孝夫 ${ }^{* *}$}

$*$ 三洋化成工業株式会社名古屋工場新改良品室 ( ( 476 愛知県東海市新宝町 31-1)

** 三洋化成工業株式会社研究本部技術開拓研究室 （宁605 京都市東山区一橋野本町 11-1）

プロポキシレーションにおける暴走反応は『PO 濃度 式』等を活用することによってシミュレーションの可能 なことは既に述べた。

それによると, 最高到達圧力は従来知られていた予測 法による值に比べてかなり低いことが予想され，かつ実 証されたが，温度は従来法とほぼ同じレベルであり，反 㐫条件によると $300^{\circ} \mathrm{C}$ を越えることが判明した。

温度上昇による災害を防止する方法を開発すること は, 30 万 $\mathrm{t}$ を越える生産量を持つプロポキシレーション にとって重要な課題である。

従来は反応缶の外壁を大量の水で冷却することなどが 提案されていたが, 適当な測定装置がなかったためその 効果の検証はされていなかった。

我々はカセイアルカリを触媒とするプロポキシレー ションにおいてリン酸を添加する事で反応の暴走を停止 できることを, 『リアクションカロリメータ RC-1』を 用いての断熱反応で実証した。

連絡者：五藤芳和 